\title{
Optimization of Managerial, Organizational and Technological Solutions of Grain Storages Construction and Reconstruction
}

\author{
Aleksandr Meneylyuk, Aleksey Nikiforov*
}

\begin{abstract}
The work is devoted to the important problem of optimization of managerial, organizational and technological solutions of construction and reconstruction of separate grain storages and the management of specialized building enterprise as a whole. Models of the company for the grain storages construction and renovation were designed, analyzed and described: multidimensional organizational structure, computer model of the enterprise. The results of a two-stage construction products cost optimization were presented. The recommendations for the adoption of optimal organizational and technological solutions were developed. The method for justification of financial income level for the grain storages construction and reconstruction using project management principles and provisions of the existing regulations was proposed.
\end{abstract}

Keywords: construction and reconstruction of the grain storages; business management techniques; multidimensional organizational structure; optimization; management; organizational and technological solutions

\section{INTRODUCTION}

The work is devoted to the important problem of optimizing the managerial, organizational and technological solutions of construction and reconstruction of separate grain storages and the management of specialized building enterprise in general.

Profitability is one of the key performance indicators in the management of individual objects in the grain storages construction or reconstruction, as well as managing the company's operational activity for the construction of such facilities. Modeling of resource assignments for construction and installation work performed during the grain storages construction or reconstruction, allows showing the full cost of production. Analysis of all construction projects, with a total budget conditionally equal to the average budget of the specialized enterprise, simulates the full structure of production costs and the profitability of such a construction organization.

It is obvious that the links are possible between different organizational and technological solutions for enterprise management in general and the construction of individual construction projects. This relationship may be modeled by multidimensional managerial structure. Its research will improve the quality of managerial decisions. Variation of organizational and technological solutions will change the structure and addends of the total production costs, the organizational structure of the enterprise. Construction of computer models of the totality of construction projects will allow tracking changes of the most important indicators of financial performance under the influence of different factors of organizational and technological nature.

The high relevance of the article is determined by large scale, special features of management of the grain storages construction and reconstruction, the absence of specific recommendations in the area under consideration and the availability of organizational and technological reserves of optimization.

\section{AIM AND TASKS OF THE ARTICLE}

This article aims to optimize the managerial, organizational and technological solutions for grain storages construction and renovation by organizational and economical mathematical modeling of operations of the specialized enterprises and the development of rational tools of their management.

Article tasks are the following:

1. Analyze information sources on the subject of research: the conditions of the grain storages construction and renovation, methods of organizational and numerical modeling.

2. Develop methodology for numerical simulation of the operating activity of the grain storages construction and renovation enterprise.

3. Develop models of the enterprise operating activity under consideration: a multi-dimensional organizational model, the computer model.

4. Get the numerical regularities of performance change in the enterprise operating activity and find the optimal organizational and technological solutions.

5. Suggest rational enterprise managerial tools for the construction and renovation of grain storages.

\section{ANALYSIS OF INFORMATION SOURCES}

Data on the segmentation of the grain storages construction market in the world [1-5] show that a significant proportion of the work is to upgrade existing storage facilities. Typically, this modernization involves the commissioning of new silos, the upgrading of technological equipment, productivity enhancement of transport lines and individual technological units of grain storage, associated with this dismantling work and the construction of small additional structures. As a rule, grain storage modernization is rarely of large scale. Grain storages reconstruction projects may have a budget up to 1 million UAH and labor input of construction and installation works up to 3 thousand hours 
$[5,6]$. Nevertheless, there are still tendencies to build new wide-scale grain storages and carry out large-scale renovation of existing ones. It can be concluded that the largest object for a typical grain storages construction and renovation enterprise has a budget of about 25-30 million $\mathrm{UAH}$ and the total labor intensity of construction and installation works for about 40 thousand hours $[5,6]$.

Analysis of types of enterprises organizational structures showed that the most common types are linear, linear-staff, project, matrix, multidimensional. The difference of these structures lies in different priorities of vertical and horizontal managerial relationships between their elements. Matrix and most multidimensional structures have the highest priority of horizontal relations among the considered structures. The development of such relations can be effective in the variable environment in which the company sells its activity [7].

It is advisable to use a simulation to improve construction activity. The most effective simulation of the operating activity of the enterprises is to build analytical, deterministic, optimizing, imitative, static, correlativeregressive, network models $[8,9]$.

The fundamental works on the organization of construction process proved that there was a correlation between the management processes of the organization and construction projects $[10,11]$. It is proposed [12], that the operations of construction enterprises may be modeled using multidimensional organizational structures.

Analysis of works, devoted to the optimization of organizational and technological solutions for construction and reconstruction [13, 14], allows the conclusion that the application of experimental statistical modeling is an effective way of solving similar problems and can be used in modeling and optimizing the operating activity of enterprises for construction and renovation of dispersed different scale buildings.

The application of experimental statistical modeling for the methods of optimization are discussed in [15-17]. Also, the methods of optimization with the application of experimental statistical modeling are presented in [18-20]. It is advisable $[21,22]$ to use specialized programs for project management to create a model of the operating activity of the construction organization.

In the course of operational activity, important issues arise in the management of enterprise costs accounting. According to numerous works [23-24], it is advisable to divide cost by the accounting standard into direct costs and general production ones.

Regulatory methods for calculating costs and revenues are based on the use of a database of resource rates per unit of physical measurement of work, regulatory indicators of general production, administrative costs and profit on the consolidated labor input of construction $[25,26]$. It is also allowed to use actual data for the calculation of general production and administrative costs indicators for construction enterprises [27, 28]. The usage of the internal database of resource rates per work unit is not prohibited for the construction company [26]. When managing projects [29], the special attention is recommended to pay to the formation of a full and detailed content and cost of the project, as well as to integrate them with the goals of the project-oriented enterprise as a whole. That means to consider the cost of the project only in the context of the organization that implements it.

\section{OVERALL METHODOLOGY OF STUDY}

Fig. 1 shows the block diagram of the experimental studies.

1) The choice of the most significant indicators of the company's operating activity and the organizational and technological factors affecting them.

2) Development of models of the grain storages construction and reconstruction projects on the basis of project drawings.

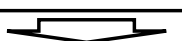

3) Simulation of the enterprise operating activity in accordance with the developed plan of experiments.

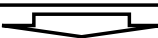

4) Construction of experimental statistical models of the indicators dependences from the studied factors using specialized software.

$$
\stackrel{r}{r}
$$

5) Two-stage optimization of the cost of construction products with a profitability limit.

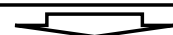

6) Development of recommendations for optimizing managerial, organizational and technological solutions for the grain storages construction and reconstruction.

Figure 1 Block diagram of the experimental studies to optimize the organizational and technical solutions grain storages construction and reconstruction enterprise

The polynomial experimental statistical (ES) model was selected in this study in order to solve optimization problems. Eq. (1) presents it in a common form:

$Y_{n}=b_{0}+b_{1} X_{1}+b_{11} X_{12}+b_{12} X_{1} X_{2}+b_{13} X_{1} X_{3}+$

$+B_{14} X_{1} X_{4}+b_{2} X_{2}+b_{22} X_{22}+b_{23} X_{2} X_{3}+B_{24} X_{2} X_{4}+$

$+b_{3} X_{3}+b_{22} X_{22}+b_{33} X_{32}+b_{34} X_{3} X_{4}+B_{4} X_{4}+b_{44} X_{42}$

The transition to the coded variables was configured by the typical equation:

$x_{i}=\frac{X_{i} \frac{X_{i \max }+X_{i \min }}{2}}{\frac{X_{i \max }-X_{i \min }}{2}}$

where: $x_{i}$ - predetermined level of factor in a normalized form; $X_{i}$ - predetermined factor level in natural form; $X_{i \max }-$ the maximum level of the factor in its natural form; $X_{i \text { min }}-$ the minimum level of factor in its natural form.

Tab. 1 presents the plan used in numerical experiment.

The calculation of the regression coefficients was carried out according to standard equations using interactive COMPEX system. The regression coefficients are statistical estimates of the true coefficients of the addendum of the polynomial model, therefore, require verification of the 
difference between estimates of coefficients of ES-models and zero. This test was carried out at bilaterally specified risk equal to $10 \%(\alpha=0.1$, or $\pm 5 \%)$, in accordance with Gaussian distribution law. After sieving coefficients, which were recognized indistinguishable from zero, ES-model with all significant coefficients was checked for adequacy by Fisher test. If the criterion was less critical for a given risk in view of the obtained degrees of freedom, i.e. $F_{\mathrm{a}}<F_{\mathrm{kr}}\left(\alpha, f_{\mathrm{na}}, f_{\mathrm{e}}\right)$, it was adequate.

Table 1 Plan of numerical experiment in coded variables

\begin{tabular}{|c|c|c|c|c|c|c|c|c|c|}
\hline$\#$ & \multicolumn{3}{|c|}{ Normalized factor values } & \# & \multicolumn{4}{|c|}{ Normalized factor values } \\
\hline & $X_{1}$ & $X_{2}$ & $X_{3}$ & $X_{4}$ & & $X_{1}$ & $X_{2}$ & $X_{3}$ & $X_{4}$ \\
\hline 1 & 2 & 3 & 4 & 5 & 1 & 2 & 3 & 4 & 5 \\
\hline 1 & 1 & 1 & 1 & 1 & 13 & -1 & -1 & 1 & 1 \\
\hline 2 & 1 & 1 & 1 & -1 & 14 & -1 & -1 & 1 & -1 \\
\hline 3 & 1 & 1 & -1 & 1 & 15 & -1 & -1 & -1 & 1 \\
\hline 4 & 1 & 1 & -1 & -1 & 16 & -1 & -1 & -1 & -1 \\
\hline 5 & 1 & -1 & 1 & 1 & 17 & 1 & 0 & 0 & 0 \\
\hline 6 & 1 & -1 & 1 & -1 & 18 & -1 & 0 & 0 & 0 \\
\hline 7 & 1 & -1 & -1 & 1 & 19 & 0 & 1 & 0 & 0 \\
\hline 8 & 1 & -1 & -1 & -1 & 20 & 0 & -1 & 0 & 0 \\
\hline 9 & -1 & 1 & 1 & 1 & 21 & 0 & 0 & 1 & 0 \\
\hline 10 & -1 & 1 & 1 & -1 & 22 & 0 & 0 & 0 & 1 \\
\hline 11 & -1 & 1 & -1 & 1 & 23 & 0 & 0 & -1 & 0 \\
\hline 12 & -1 & 1 & -1 & -1 & 24 & 0 & 0 & 0 & -1 \\
\hline & & & & & 25 & 0 & 0 & 0 & 0 \\
\hline
\end{tabular}

The computer model of the operating activity of the enterprise was considered as the system under investigation. This model was variable under the action of studied factors according to the experimental design.

Fig. 2 presents the method of modeling the total production cost and the cost of construction products for grain storages construction and renovation. Fig. 3 shows the method of modeling the profitability of the enterprise in question in accordance with the recommendations of normative documents of Ukraine [28].

\section{MODELING OF OPERATING ACTIVITY OF GRAIN STORAGES CONSTRUCTION AND RECONSTRUCTION ENTERPRISE}

Tab. 2 presents description of the elements of the developed models.

Construction products can be described as a set of indicators, by which they are shown. It can be written that the construction products are characterized by the following performance indicators (Eq. (3)):

$$
I C P \subseteq\left\{\left\{Y_{\text {tech. }}\right\},\left\{Y_{\text {econ. }}\right\},\left\{Y_{\text {env. }}\right\},\left\{Y_{\text {soc. }}\right\}\right\}
$$

Table 2 The determinants of the organizational structure of the enterprise business processes of the grain storages construction and renovation enterprise

\begin{tabular}{|c|l|}
\hline Designation & Full title \\
\hline ICP & - indicators of construction products \\
\hline DCC & - departments of construction company \\
\hline R & - resources for the building production \\
\hline MCE & - management of construction enterprise \\
\hline MCP & - management of construction project \\
\hline S & - suppliers \\
\hline WBS & - work breakdown structure \\
\hline
\end{tabular}

1) Analysis of project documentation and calculation of physical volumes of construction and installation works.

\section{$+2$}

2) Calculation of direct costs of construction objects by multiplying physical volumes by the actual resource cost calculated on the basis of actual data and by market-based resource rates:

- when changing the resource cost rate in accordance with the the factor "the ownership of the resources used";

- when changing the time rate of resources in accordance with the factors "average labor intensity of the complex of projects", "industriality of the used solutions".

\section{L}

3) Calculation of general production costs of construction by multiplying the expenditure items by current prices:

- when changing the initial data in accordance with the factors "average

labor intensity of the complex of projects", "average relocation distance".

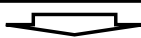

4) Fixing costs values for sets of construction objects according to the plan of experiments.

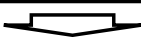

5) Calculation of values of cost indicators for construction products.

Figure 2 Method of modeling the full production costs and the cost of construction products

1) Analysis of project documentation and calculation of physical volumes of construction and installation works.

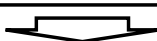

2) Calculation of the direct costs of construction objects by multiplying physical volumes by the normatively established time rate of resources for work and by market-based resource rates.

\section{$\longrightarrow$}

3) Calculation of general production costs of construction objects by multiplying the source data by current prices for items of expenditure:

- when changing the initial data in accordance with the action factors "average labor intensity of the complex of projects", "average relocation distance".

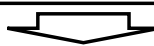

4) Calculation of general production costs of construction by:

- determination the cost of engineering and technical workers and payroll workers;

- determination the costs of other general production items, taking into account the overall labor input, the normative coefficient and the class of consequences of the object.

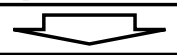

5) Calculation of the administrative costs of construction projects, taking into account the overall labor input, the normative coefficient and the class of consequences of the object.

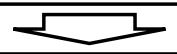

6) Calculation of income for construction projects, taking into account the overall labor input, the normative coefficient and class of consequences of the object.

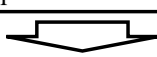

7) Fixing costs values for sets of construction objects according to the plan of experiments.

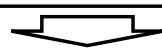

8) Calculation of the value of the indicator "profitability".

Figure 3 Method of modeling profitability of the enterprise in accordance with the recommendations of normative documents

where: $\left\{Y_{\text {tech. }}\right\}$-indicators of technical efficiency; $\left\{Y_{\text {econ. }}\right\}-$ indicators of economic efficiency; $\left\{Y_{\text {env. }}\right\}$ - indicators of environmental efficiency; $\left\{Y_{\text {soc. }}\right\}-$ indicators of social efficiency. 
In this study, the following indicators were suggested:

- $\quad Y_{1}$ - profitability - the percentage ratio between the value of the total production costs, calculated on the basis of actual operating data of the enterprise, and the value of income, calculated in accordance with the regulatory procedure. Such revenues include compensation for direct costs of general production, administrative costs and profit.

- $\quad Y_{2-6}-$ Cost of construction products - direct costs of the construction products. The cost prices were calculated for the following main units: the concrete structures arrangement $\left(Y_{2}-1 \mathrm{~m}^{3}\right)$, installation of bearing steel structures $\left(Y_{3}-1 \mathrm{t}\right.$.), silo $\left(Y_{4}-1 \mathrm{~m}^{3}\right)$, the transport equipment installation (noria $\left(Y_{5}\right)$, conveyor $\left(Y_{6}\right)-1 \mathrm{~m}$ ). Thus, the construction products (ICP indicators) included for the present study: (Eq. (4))

$$
I C P \subseteq\left\{Y_{1}, Y_{2}, Y_{3}, Y_{4}, Y_{5}, Y_{6}\right\}
$$

Tab. 3 shows the variation matrix of factors taken in this study as the input parameters of the system under study.

Table 3 Matrix variation factors

\begin{tabular}{|l|c|c|c|}
\hline \multicolumn{1}{|c|}{ Factor name } & \multicolumn{3}{|c|}{ Factor levels } \\
\cline { 2 - 4 } & -1 & 0 & +1 \\
\hline $\begin{array}{l}X_{1} \text { - average labor input of the } \\
\text { projects totality }\end{array}$ & $\begin{array}{c}2.2 \\
\text { thousands } \\
\text { hours }\end{array}$ & $\begin{array}{c}19.6 \\
\text { thousands } \\
\text { hours }\end{array}$ & $\begin{array}{c}37 \\
\text { thousands } \\
\text { hours }\end{array}$ \\
\hline$X_{2}$ - average relocation distance & $100 \mathrm{~km}$ & $550 \mathrm{~km}$ & $1000 \mathrm{~km}$ \\
\hline$X_{3}$ - membership of resources used & $0 \%$ & $50 \%$ & $100 \%$ \\
\hline $\begin{array}{l}X_{4} \text { - industriality of applied } \\
\text { solutions }\end{array}$ & $0 \%$ & $50 \%$ & $100 \%$ \\
\hline
\end{tabular}

Considered indicators and factors, as well as internal determinants, can be presented as a multi-dimensional organizational structure of the enterprise management for the grain storages construction and renovation (Fig. 4).

Multidimensional structure shown in Fig. 4 allows to group construction projects performed by the organization, depending on their scale $\left(X_{1}\right)$ and territorial dispersion $\left(X_{2}\right)$. This makes it possible to analyze the technological organizational relationship between such construction projects. Various organizational and technological solutions $\left(X_{3}, X_{4}\right)$ are possible while performing construction works on individual projects. The model shows that there is a relationship between the organizational structure (DCC) and its managerial methods (MCE), as well as between the structure (WBS) and control methods (MCP) of individual projects. It can be noted that the resources (R: labor, material, technical, intellectual, financial, and technology), used in the creation of construction products, can be put in order through the project work breakdown structure (WBS). As seen from the figure, the developed multidimensional managerial structure is a tool for transforming external resources provided by suppliers into construction products.

Developed multidimensional organizational structure (Fig. 4) allowed solving one of the problems of the rationalization of managerial, organizational and technological solutions of grain storages construction and reconstruction- improving organizational structures of considered enterprises. Namely, the rationalization was possible due to a new approach to:

- formalizing the management interactions between elements of the considered companies operating activity in vertical and horizontal directions;

- $\quad$ organization of operating activity of enterprises under consideration and construction projects logistics at various levels of variable factors.

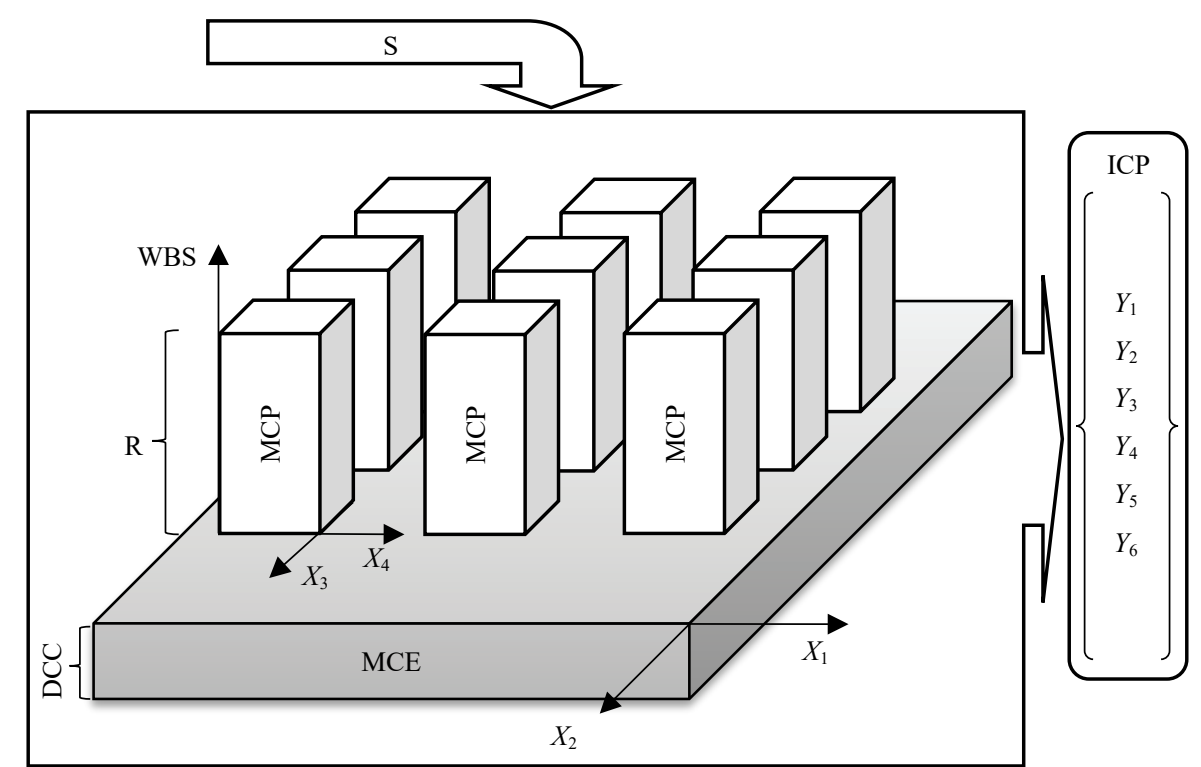

Figure 4 The multidimensional organizational structure of the grain storages construction and reconstruction enterprise

It is necessary for the success of the numerical experiment: to build a trustworthy computer model of the system under study; to choose the input and output parameters - factors and indicators. Data of the construction projects was used to create a computer model of the optimization of the operating activity of the grain storages 
construction and reconstruction enterprise. Its structure is presented in the graphical analytical form in Fig. 5.

The presented computer model (Fig. 5) was variable, as the levels of its input parameters (factors) vary in the numerical experiment. The variability of computer model was possible under the influence of each factor by:

- $X_{1}$ - the average labor input of the projects totality. The compliance of a considering set of projects with the desired value of the variation characteristic should be ensured - the arithmetic mean of labor input of construction and installation works on the projects of this totality.

- $X_{2}-$ the average relocation distance. The necessary value of the variation characteristic (the arithmetic mean of distances relocation of resources between any two objects of the chosen totality) was taken as an input when calculating the cost of relocation of industrial and household premises, vehicles, machinery and construction equipment as a part of general production costs.

- $X_{3}-$ membership of resources used. The difference of using the subcontract resources in comparison with the own resources was characterized as follows: unit prices for the resource (labor, machinery or equipment) are higher by $18 \%$, which is justified by the market situation in Ukraine. However, the cost of relocation of industrial and household premises, vehicles, machinery and construction equipment will be lower, since the involvement of subcontractors is desirable when their material and technical supply base is closer to the construction site. In this study, it is accepted that the use of subcontractor resources relocation costs is reduced by 2 times. This change is introduced together with the varying of the $X_{2}$ factor.

- $X_{4}$ - industriality of applied solutions. This factor had a complex effect on the methods of work production of the grain storages construction and renovation. The use of industrial methods allowed achieving this: pre-prepared construction equipment, materials, products and structures; the streamflow organization of production operations; the mechanization rate of work. Simulation of this factor is done by resource assignments adjustment of corresponding works.

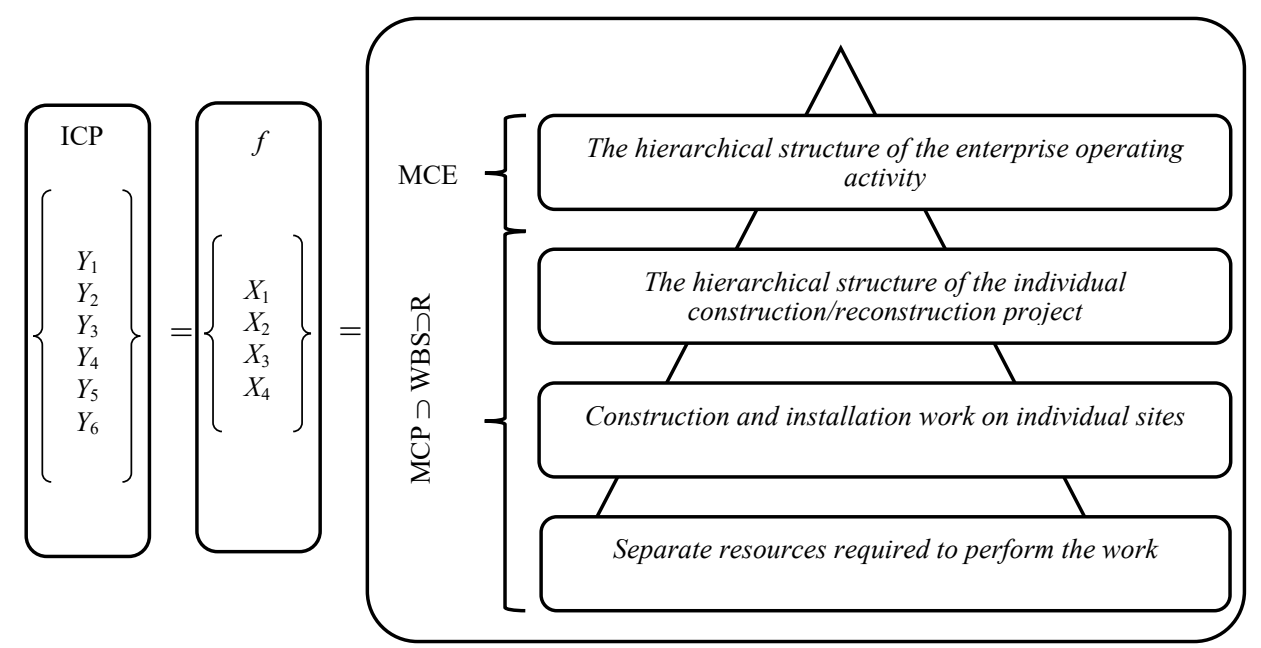

Figure 5 Graphical analytical form of a computer model of the operating activity of the grain storages construction and renovation enterprise

\section{OPTIMIZATION OF ORGANIZATIONAL AND TECHNOLOGICAL SOLUTIONS OF GRAIN STORAGES CONSTRUCTION AND RECONSTRUCTION}

Tab. 4 presents the results of the experimental statistical modeling.

The indicator changes of profitability are presented in Eq. (5). Factors, recognized by Student's test as indistinguishable from zero, are not shown here or below.

$$
\begin{aligned}
& Y_{1}=11.5549-0.2591 X_{1}-0.0178 X_{2}-0.0761 X_{3}- \\
& -0.0467 X_{4}+0.0024 X_{1} X_{2}+0.0004\left(X_{1} X_{2}+X_{1} X_{4}\right)
\end{aligned}
$$

Analysis of addendum characters of the Eq. (5) showed that the influence of the factor $X_{1}$ ("average labor input of projects totality") increments the profitability $\left(Y_{1}\right)$ both in in its individual influence and when combined with other influencing factors. However, the individual influence of factors $X_{2}$ ("average relocation distance") and $X_{3}$ ("membership of resources used") reduces the indicator value.

The most convenient graphical representation of the analytical dependence of the four factors is the chart "squares on the square". It reflects the change of the indicator from two factors within nine "small" squares, which are located on the "big" square, showing nine combinations of the values of the other two factors.

Fig. 6 shows the regularity of profitability change $\left(Y_{1}\right)$ from the membership of resources used $\left(X_{3}\right)$ and the industriality of applied solutions $\left(X_{4}\right)$ for nine combinations of values of the average labor input of the projects totality $\left(X_{1}\right)$ and the average relocation distance $\left(X_{2}\right)$.

Hereafter, the indicator extrema within two-factor diagrams are marked by bold; the extrema within the entire diagrams - underlined; factor levels values - italics. 
The analysis of Fig. 6 allowed noting the following. The character of factor influence "industriality of applied solutions" $\left(X_{4}\right)$ does not change depending on the level of factor "average relocation distance" $\left(X_{2}\right)$, but is different at different levels of the factor "average labor input of the projects totality" $\left(X_{1}\right)$.

Magnification of factor $X_{4}$ reduces the value of the indicator when $X_{1}=2.2$ thous. hours; factor $X_{4}$ does not affect indicator when $X_{1}=19.6$ thous. hours; factor $X_{4}$ increases the value of the indicator when $X_{1}=37$ thous. hours. Character of influence of factor "membership of resources" $\left(X_{3}\right)$ changes depending on the area of factors' space: the parameter decreases with increasing of levels of this factor.

Thus, it was concluded that the application of subcontracting forces on the grain storages construction and reconstruction facilities reduces the profitability of $5-7 \%$ at all levels of strategic factors of organizational technological nature. Application of industrial construction methods can only be justified on large ( $X_{1}=37$ thous. hours) grain storages construction and reconstruction facilities, increasing the profitability from 3.24 to $5.1 \%$. Such methods reduce profitability of $2.31-4.4 \%$ on small objects $\left(X_{1}=2.2\right.$ thous. hours).

Table 4 Results of the experimental statistical modeling

\begin{tabular}{|c|c|c|c|c|c|c|}
\hline \multirow[b]{2}{*}{ \# } & \multicolumn{6}{|c|}{ Indicators } \\
\hline & $\begin{array}{c}\text { Profitability, } \\
Y_{1}\end{array}$ & $\begin{array}{c}\text { Cost of reinforced concrete } \\
\text { structures unit, } Y_{2} \\
\text { (thous. UAN } / \mathrm{m}^{3} \text { ) }\end{array}$ & $\begin{array}{c}\text { Cost of load-bearing metal } \\
\text { structures unit, } Y_{3} \\
\text { (thous. UAN/ton) }\end{array}$ & $\begin{array}{l}\text { Cost of grain silo storage } \\
\text { installation, } Y_{4}, \\
\text { (UAN } / \mathrm{m}^{3} \text { storage) }\end{array}$ & \begin{tabular}{|c|} 
Cost of noria section \\
installation, $Y_{5}$ \\
(thous. UAN $/ \mathrm{m}$ )
\end{tabular} & $\begin{array}{l}\text { Cost of conveyor section } \\
\text { installation, } Y_{6}(\mathrm{UAN} / \mathrm{m})\end{array}$ \\
\hline 1 & $-2.24 \%$ & $3,276.17$ & $4,653.77$ & 41.50 & $1,196.46$ & 794.88 \\
\hline 3 & $2.92 \%$ & $3,162.74$ & $4,046.76$ & 36.13 & $1,040.40$ & 709.00 \\
\hline 4 & $-1.20 \%$ & $3,627.29$ & $4,496.40$ & 43.24 & $1,156,00$ & 787.77 \\
\hline 5 & $0.11 \%$ & $3,276.17$ & $4,653.77$ & 41.50 & $1,196.46$ & 794.88 \\
\hline 8 & $2.08 \%$ & $3,627.29$ & $4,496.40$ & 43.24 & $1,156.00$ & 787.77 \\
\hline 9 & $-17.65 \%$ & $3,888.06$ & $4,653.77$ & 72.88 & $1,218.85$ & 843.68 \\
\hline 10 & $-13.65 \%$ & $3,722.22$ & $5,170.86$ & 87.43 & $1,314.07$ & 937.42 \\
\hline 11 & $-9.83 \%$ & $3,736.82$ & $4,046.76$ & 63.49 & $1,059.87$ & 752.42 \\
\hline 12 & $-6.32 \%$ & $3,586.13$ & $4,496.40$ & 76.16 & $1,142.67$ & 836.02 \\
\hline 13 & $-1.81 \%$ & $3,888.06$ & $4,653.77$ & 72.88 & $1,218.85$ & 843.68 \\
\hline 19 & $-3.74 \%$ & $3,448.75$ & $4,591.95$ & 43.04 & $1,188,16$ & 818.38 \\
\hline 20 & $0.36 \%$ & $3,448.75$ & $4,591.95$ & 43.04 & $1,188.16$ & 818.38 \\
\hline 21 & $-4.87 \%$ & $3,511.51$ & $4,912.32$ & 46.01 & $1,271.05$ & 865.33 \\
\hline 22 & $-2.82 \%$ & $3,286.01$ & $4,653.77$ & 41.97 & $1,205.04$ & 819.87 \\
\hline 23 & $1.49 \%$ & $3,385.98$ & $4,271.58$ & 40.06 & $1,105.26$ & 771.43 \\
\hline 24 & $-3.61 \%$ & $3,678.66$ & $4,833.63$ & 46.98 & $1,249.87$ & 861.37 \\
\hline 25 & $-1.69 \%$ & $3,448.75$ & $4,591.95$ & 43.04 & $1,188.16$ & 818.38 \\
\hline
\end{tabular}

In general, there was negative profitability in many areas of the investigated factor space when considering the income, calculated in accordance with the recommendations of existing regulations and the expenses calculated according to the analysis of the actual costs of the grain storages construction and reconstruction enterprise. This proved that the regulatory methods for calculating construction companies' income are imperfect.

Considered data showed that the method of calculating the general production and administrative costs, which is recommended in current regulations, is not effective enough to calculate the construction companies who build on sites with a small distance relocation (profitability is $Y_{1}=1.78 \div$ 9.3\%). In addition, it is ineffective for enterprises which build the objects with an average relocation distance more than $\mathrm{X}_{2}$ $=625 \mathrm{~km}$ (profitability decreases to $Y_{1}=-17.58 \%$ ). Also, the operating activity of companies specializing in the construction on small-scale sites $\left(X_{1}=2.2\right.$ thous. hours) becomes unprofitable at average relocation distance equal $X_{2}$ $=495 \mathrm{~km}$.

All of the above proves that the most effective approach is to use project-based methods to justify the income value, especially for the general production costs, administrative costs. Namely, to conduct detailed calculation of all items of expenditure according to $\S 4.3 .8,5.3 .6$ of the [9]. There cannot be is invited to apply the additional calculation of general production, administrative costs to the calculation of direct costs. $0.6-4.5 \%$ of profitability can be reached by taking into account the additional calculation of general production, administrative costs for enterprises operating activity. Such low profitability values require the use of a project approach to the justification of the estimated profit ( $\S$ 6.1.2 instructions [9]).

The profit value can be justified in the construction contract based on simulation and considering:

- the degree of uniqueness of erected structure; 
- the need to form a temporary project management team for work in special conditions;
- one-night performance of the construction project, respectively, the unique nature of the distribution of profit over time.

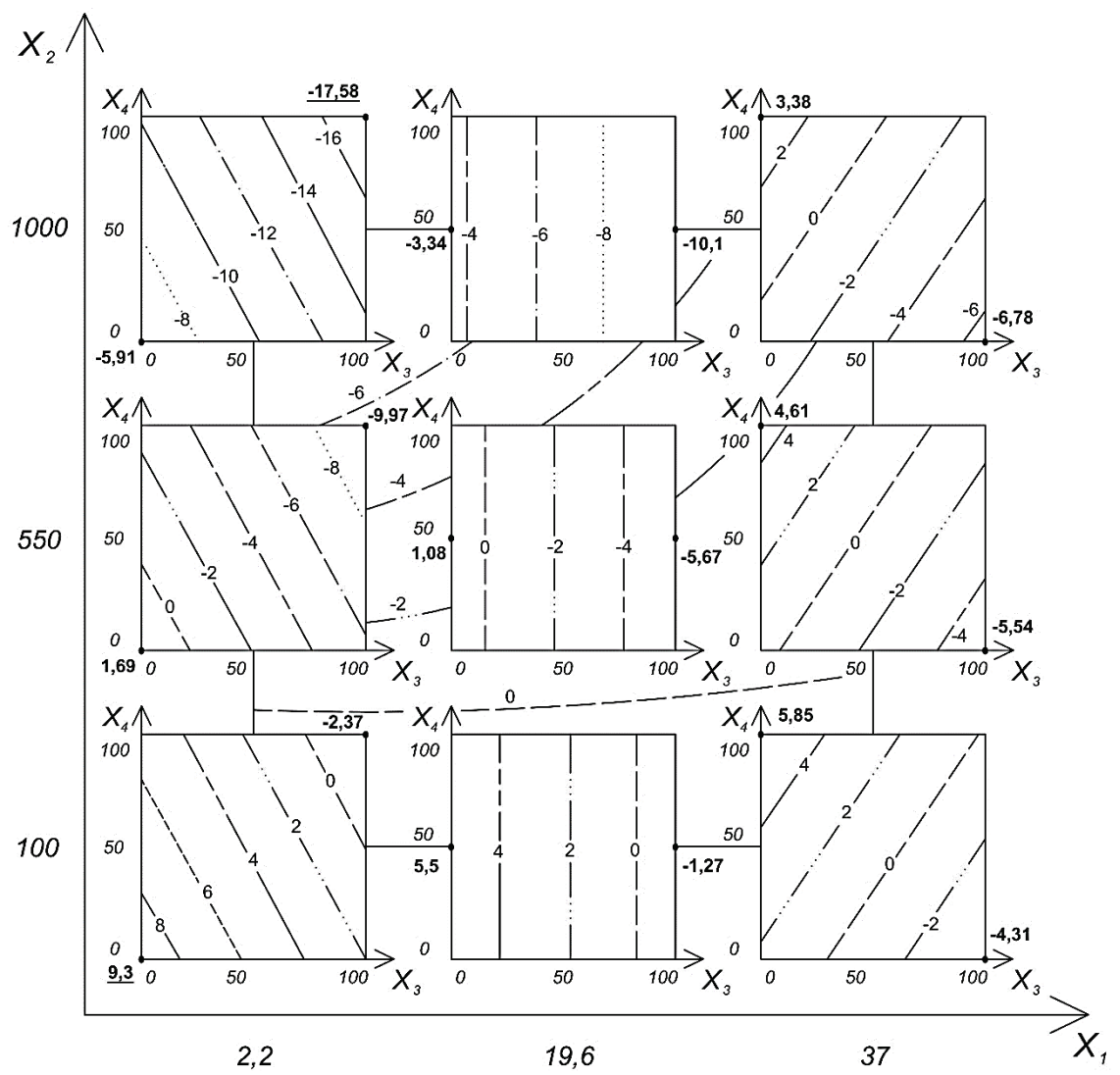

Figure 6 Change of profitability $\left(Y_{1}, \%\right)$ depending on membership of resources used $\left(X_{3}, \%\right)$ and industriality of applied solutions $\left(X_{4}, \%\right)$ at various strategic solutions of the enterprise management

The indicator changes of cost of reinforced concrete structures unit $\left(Y_{2}\right)$ are represented in analytical form in Eq. (6):

$$
\begin{aligned}
& Y_{2}=3634.4-16.475 X_{1}+0.453 X_{1}^{2}-0.183 X_{1} X_{4}+ \\
& +1.339 X_{3}-1.801 X_{4}
\end{aligned}
$$

The analysis of Eq. (6) showed that increasing of factors "average labor input of the projects totality" $\left(X_{1}\right)$ and "industriality of applied solutions" $\left(X_{4}\right)$ reduces the value of indicator $Y_{2}$, while the factor "membership of resources used" $\left(X_{3}\right)$ increases. This is indicated by addendum characters of the first degree corresponding variables. Large scale construction sites allow to use industrial methods of work, as well as to increase productivity through the use of in-line production of work. The savings due to the involvement of closely spaced resources without the need to spend money to reline are not taken into account, since the cost of construction products includes only the direct costs.

The optimization of cost of construction products was carried out according to the results of constructing regularities of these parameters change. The first step of optimization was to identify the areas of financially effective organizational and technological solutions for the enterprise as a whole. The indicator "profitability" $\left(Y_{1}\right)$ was chosen as the first stage optimization criterion. Those areas were chosen as the effective in which profitability is equal to or more than zero. The second stage of the optimization was to determine the minimum values of the cost of construction products. The search was conducted only in the areas chosen by the first stage of optimization. Namely, in the areas of finance effective organizational and technological solutions.

Fig. 7 contains the results of optimization of the cost of reinforced concrete structures unit $\left(Y_{2}\right)$ influenced by membership of resources used $\left(X_{3}\right)$ and the degree of industriality of applied solutions $\left(X_{4}\right)$ at various values of strategic solutions factors in the management of construction organizations. The analysis of Fig. 7 shows that character of factor $X_{4}$ influence differs depending on the level of factor $X_{1}$. The use of industrial organization and technological solutions on small sites is impractical, since it increases the cost of reinforced concrete structures arrangement. The minimum value of $Y_{2}$ indicator is 3.6 thous. $\mathrm{UAN} / \mathrm{m}^{3}$ when $X_{1}=2.2$ thous. hours; 3.29 thous. $\mathrm{UAN} / \mathrm{m}^{3}-$ when $X_{1}=19.6$ thous. hours; 3.14 thous. UAN $/ \mathrm{m}^{3}-$ when $X_{1}=37$ thous. hours.

The decrease in the optimized indicator is correlated with an increase of "profitability" $\left(Y_{1}\right)$ in all areas of the factor space. The closely placed sites show the highest efficiency of 
cost of reinforced concrete structures unit in all operating activity of the considered enterprise. The minimum value of cost of reinforced concrete structures unit $\left(Y_{2}\right)$ is equal to:

$Y_{2 \min }=3.14$ thous. $\mathrm{UAN} / \mathrm{m}^{3}\left(X_{1}=37\right.$ thous. hours; $X_{3}=$ $\left.0 \% ; X_{4}=0 \%\right)$.

Eq. (7) represents the dependence of cost of load-bearing metal structures unit $\left(Y_{3}\right)$ from the studied organizational and technological factors:

$$
\begin{aligned}
& Y_{3}=4576.419+8.664 X_{3}-0.019 X_{3}^{2}-0.007 X_{3} X_{4}- \\
& -8.308 X_{4}+0.041 X_{4}^{2}
\end{aligned}
$$

Let us consider Fig. 8. It graphically shows the optimization of the cost of load-bearing metal structures unit $\left(Y_{3}\right)$ influenced by membership of resources used $\left(X_{3}\right)$ and the industriality of applied solutions $\left(X_{4}\right)$. Analysis of Fig. 8 showed that increasing the level of factor $X_{3}$ ("membership of resources used") enhances the average value of indicator $Y_{3}$ by 1.14 times; increasing the level of factor $X_{4}$ ("industriality of applied solutions") reduces it by 1.1 times. The action of factors meets their organizational and technological sense: attraction of expensive resources increases the cost of installation of metal structures, the use of industrial methods of work reduces the cost of the production process.

The minimum indicator $Y_{5}$ value is equal to the following under any strategic decisions of management of the grain storages construction and reconstruction enterprises except the $\left(X_{1}=2.2\right.$ thous. hours; $\left.X_{2}=550 \mathrm{~km}\right)$ :

$Y_{3 \min }=4.16$ thous. UAN/ton $\left(X_{3}=0 \% ; X_{4}=100 \%\right)$.

Eq. (8) represents the regularity of change of cost of grain silo storage installation $\left(Y_{4}\right)$ is in analytical form:

$$
\begin{aligned}
& Y_{4}=82.312-2.932 X_{1}+0.051 X_{1}^{2}-0.001 X_{1} X_{3}+ \\
& +0.002 X_{1} X_{4}+0.112 X_{3}-1.5 \times 10^{-4} X_{3} X_{4}-0.126 X_{4}
\end{aligned}
$$

Eq. (8) showed that enhancing levels of factors $X_{1}$ ("average labor input of the projects totality") and $X_{4}$ ("industriality of applied solutions") reduces the value of the indicator $Y_{4}$; increasing level of factor $X_{3}$ ("membership of resources used") increases. Signs of the corresponding coefficients of the formula indicate this.

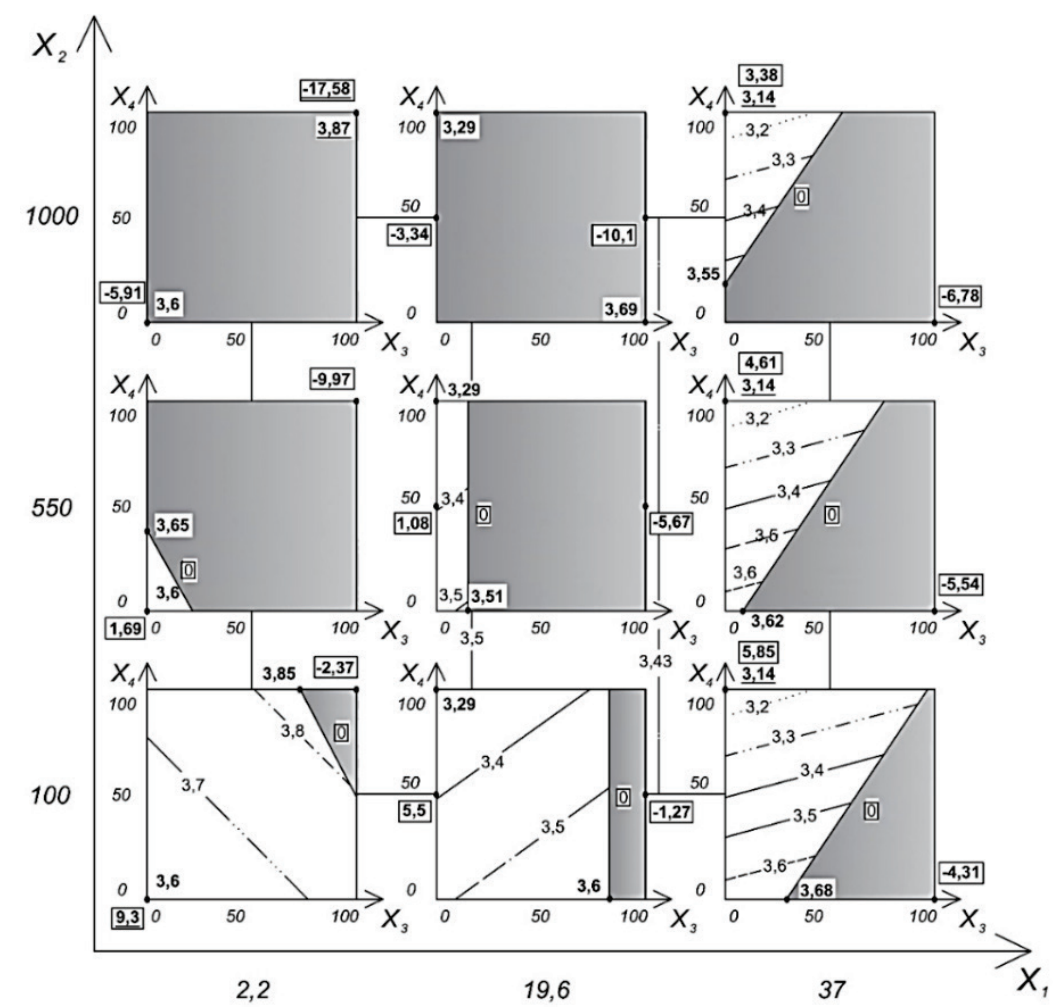

Figure 7 Optimization of cost of reinforced concrete structures unit $\left(Y_{2}\right.$, thous. UAN/m3 $)$ influenced by membership of resources used $\left(X_{3}, \%\right)$ and industriality of applied solutions $\left(X_{4}, \%\right)$ at various strategic solutions of the enterprise management and under limitation of $Y_{1} \geq 0 \%$

Fig. 9 contains the results of the optimization of cost of grain silo storage installation $\left(Y_{4}\right)$ under the influence of membership of resources used $\left(X_{3}\right)$ and the industriality of applied solutions $\left(X_{4}\right)$ at different levels of the strategic organizational and technological factors $\left(X_{1}\right.$ and $\left.X_{2}\right)$.

The nature of the influence of factors $X_{3}$ and $X_{4}$ does not change at the different levels of the factor $X_{1}$, as Fig. 9 presents. In case of small amounts of work
$\left(X_{1}=2.2\right.$ thous. hours) membership of resources used $\left(X_{3}\right)$ and industriality of applied solutions $\left(X_{4}\right)$ change indicator $Y_{4}$ in the range of 63.8 to $86.88 \mathrm{UAN} / \mathrm{m}^{3}$ storage; in case of medium amounts ( $X_{1}=19.6$ thous. hours $)$ - from 36.66 to $52.75 \mathrm{UAN} / \mathrm{m}^{3}$ storage; in case of large amounts $\left(X_{1}=37\right.$ thous. hours) - from 34.88 to $43.13-48.02 \mathrm{UAN} / \mathrm{m}^{3}$ storage (dependent on the level $X_{2}$ ). 


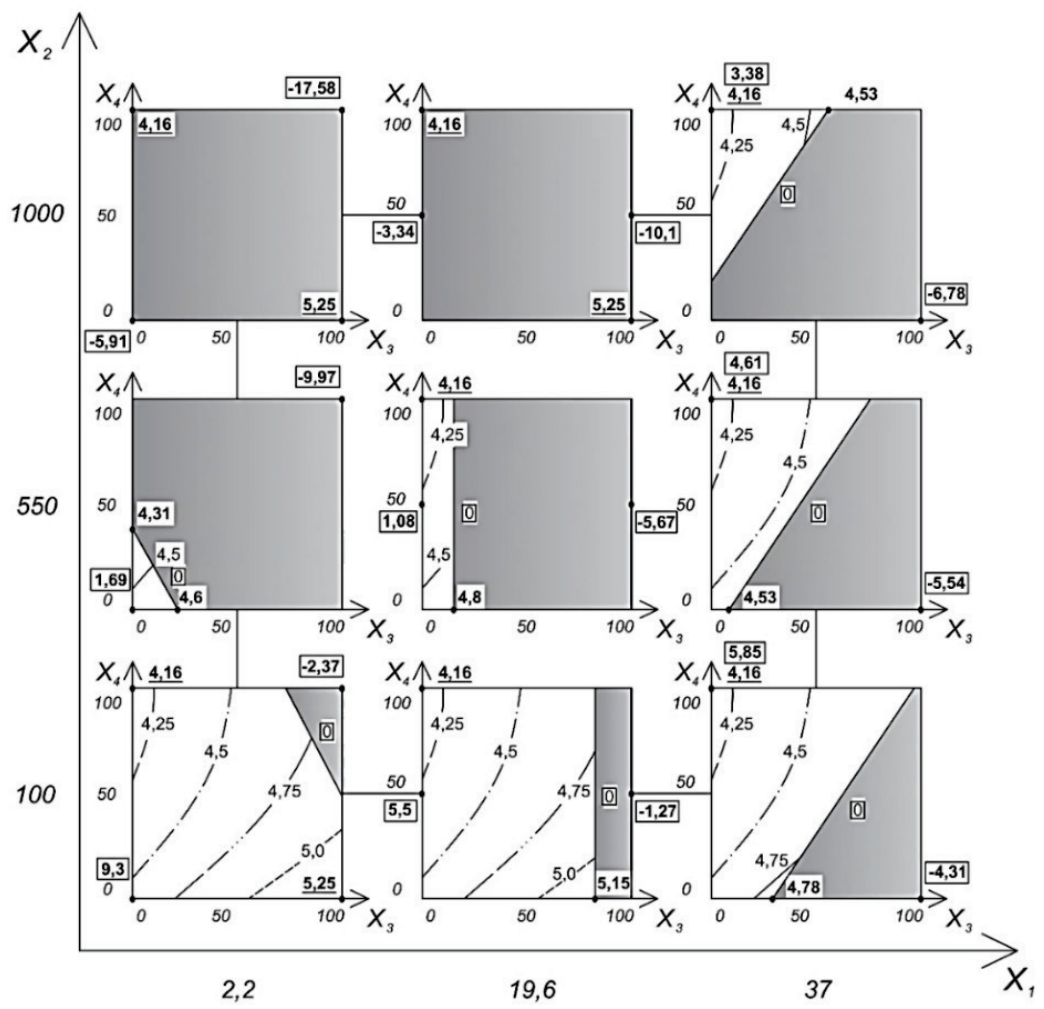

Figure 8 Optimization of cost of load-bearing metal structures unit, $Y_{3}$ (thous. UAN/ton) influenced by membership of resources used $\left(X_{3}, \%\right)$ and industriality of applied solutions $\left(X_{4}, \%\right)$ at various strategic solutions of the enterprise management and under limitation of $Y_{1} \geq 0 \%$

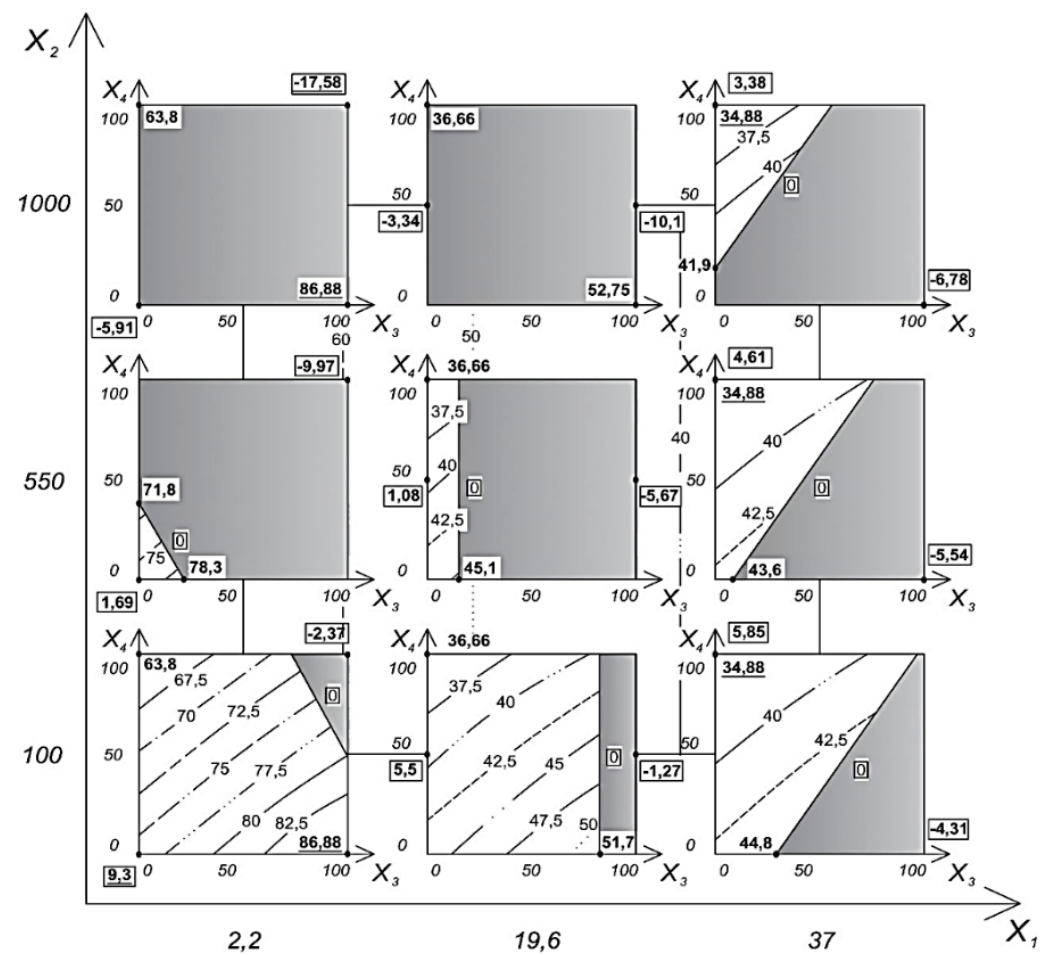

Figure 9 Optimization of cost of grain silo storage installation, $Y_{4},\left(\mathrm{UAN} / \mathrm{m}^{3}\right.$ storage) influenced by membership of resources used $\left(X_{3}, \%\right)$ and industriality of applied solutions $\left(X_{4}, \%\right)$ at various strategic solutions of the enterprise management and under limitation of $Y_{1} \geq 0 \%$

Thus, the minimum value of the indicator was achieved at all levels of strategic organizational and technological solutions, except for $\left(X_{1}=2.2\right.$ thous. hours; $\left.X_{2}=550 \mathrm{~km}\right)$, with the values of two other factors $\left(X_{3}=0 \% ; X_{4}=100 \%\right)$.
A large change of the indicator was observed for the following reasons:

- A significant share of the cost structure for silo storages assembling is occupied by manpower, machines and 
mechanisms (in the considered model of the enterprise operating activity $-87 \%$ ). Subcontractors' resources significantly increase the cost of production of such works.

- Proposed industrial solution (usage of hydraulic jacks for wall mounting) greatly optimizes silo installation process by increasing the intensity and the degree of safety of works.

Cost of grain silo storage installation $\left(Y_{4}\right)$ has the minimum value at $\left(X_{1}=0 \% ; X_{2}=100 \%\right)$ in all areas of the space factor, where this restriction does not preclude $Y_{1} \geq 0 \%$. In this case, the minimum point is still close to these levels of factors

Eq. (9) presents the change of cost of noria section installation $\left(Y_{5}\right)$ from the organizational and technological factors:

$$
\begin{aligned}
& Y_{5}=1180.606+2.221 X_{3}-0.005 X_{3}^{2}-0.002 X_{3} X_{4}- \\
& -1.461 X_{4}+0.011 X_{4}^{2}
\end{aligned}
$$

Let us consider Fig. 10. The results of cost optimizing of noria section installation $\left(Y_{5}\right)$ are shown in it graphically.

Analysis of Fig. 10 showed that enhancing the value of factor $\mathrm{X}_{3}$ increases the average value of indicator $Y_{5}$ by 0.17 thous. UAN; increasing the value of factor $X_{4}$ - decreases by 0.1 thous. UAN.

The minimum values of indicator levels for all combinations of factors $X_{1}$ ("average labor input of the projects totality") and $X_{2}$ ("average relocation distance") were observed at the point $\left(X_{3}=0 \% ; X_{4}=100 \%\right)$ and are equal to $Y_{5 \mathrm{~min}}=1.08$ thous. UAN/m. Exception is the area at $\left(X_{1}=2.2\right.$ thous. hours; $\left.X_{2}=550 \mathrm{~km}\right)$. It's minimum value of indicator "cost of noria section installation" $\left(Y_{5}\right)$ is located at a point $\left(X_{3}=0 \% ; X_{4}=40 \%\right)$ and is equal to $Y_{5 \min }=1.12$ thous. UAN/m.

The regularity of cost changes of conveyor section installation $\left(Y_{6}\right)$ by factors studied is represented in Eq. (10):

$$
\begin{aligned}
& Y_{6}=844.439-0.449 X_{1}-0.024 X_{1}^{2}+1.216 X_{3}- \\
& -2.8 \times 10^{-3} X_{3}^{2}-1.42 X_{4}+6.08 \times 10^{-3} X_{4}^{2}
\end{aligned}
$$

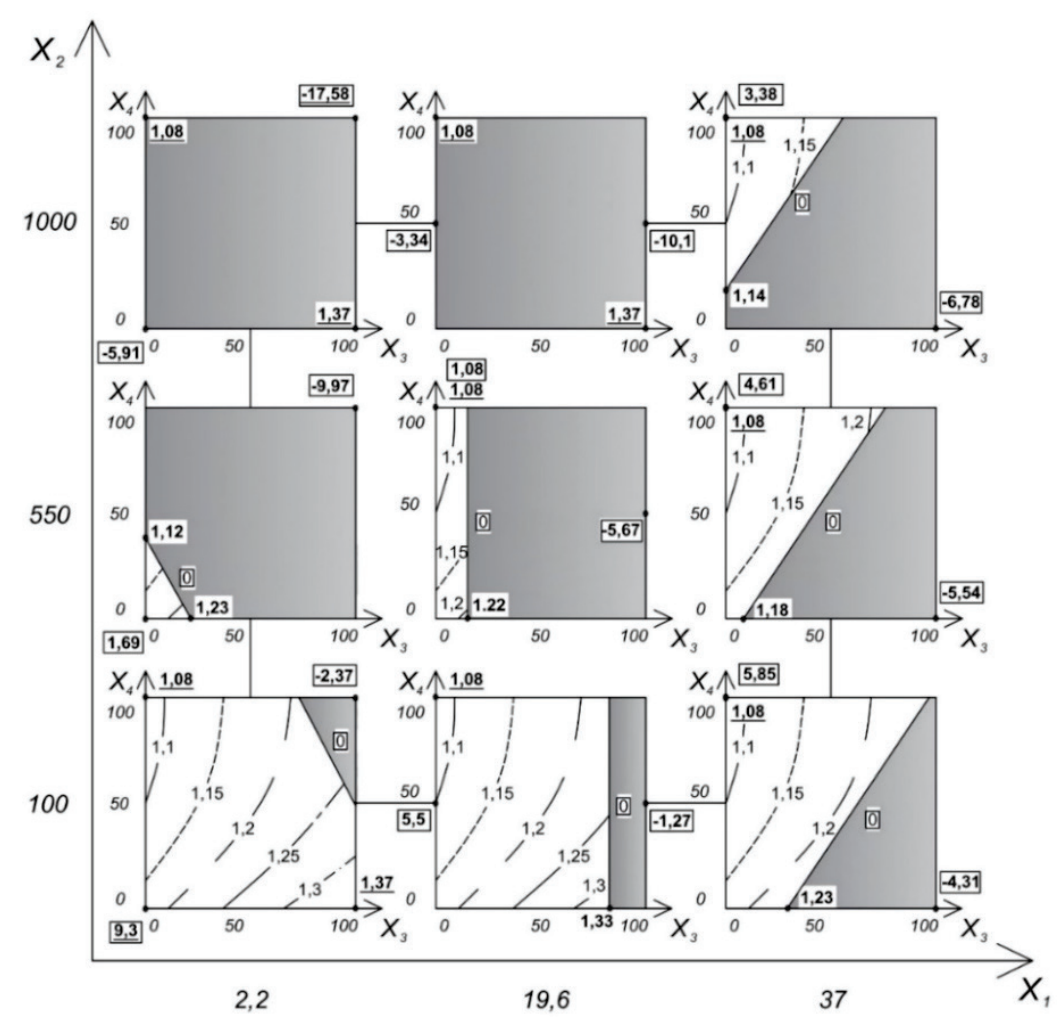

Figure 10 Optimization of cost of noria section installation, $Y_{5}$ (thous. UAN/m) influenced by membership of resources used $\left(X_{3}, \%\right)$ and industriality of applied solutions $\left(X_{4}, \%\right)$ at various strategic solutions of the enterprise management and under limitation of $Y_{1} \geq 0 \%$

Fig. 11 comprises a graphical representation of the optimization of the cost of conveyor section installation $\left(Y_{6}\right)$ under the influence of membership of resources used $\left(X_{3}\right)$ and the industriality of applied solutions $\left(X_{4}\right)$ for various combinations of levels of the factors "average labor input of the projects totality" and "average relocation distance" ( $X_{1}$ and $X_{2}$ ).

Analysis of Fig. 11 indicates that the character of the influence of factors $X_{3}$ and $X_{4}$ on the indicator $Y_{6}$ does not change depending on the factor $X_{1}$ level. The optimal use of organizational and technological solutions at objects of any size allows to reduce the value of the indicator at $67-156$ $\mathrm{UAN} / \mathrm{m}$. of conveyor on $9.5-22 \%$.

The minimum value of the indicator $Y_{6}$ is at $\left(X_{3}=0 \%\right.$; $X_{4}=100 \%$ ) under any strategic decisions of management of the grain storages construction and reconstruction enterprise than $\left(X_{1}=2.2\right.$ thous. hours; $\left.X_{2}=550 \mathrm{~km}\right)$. 


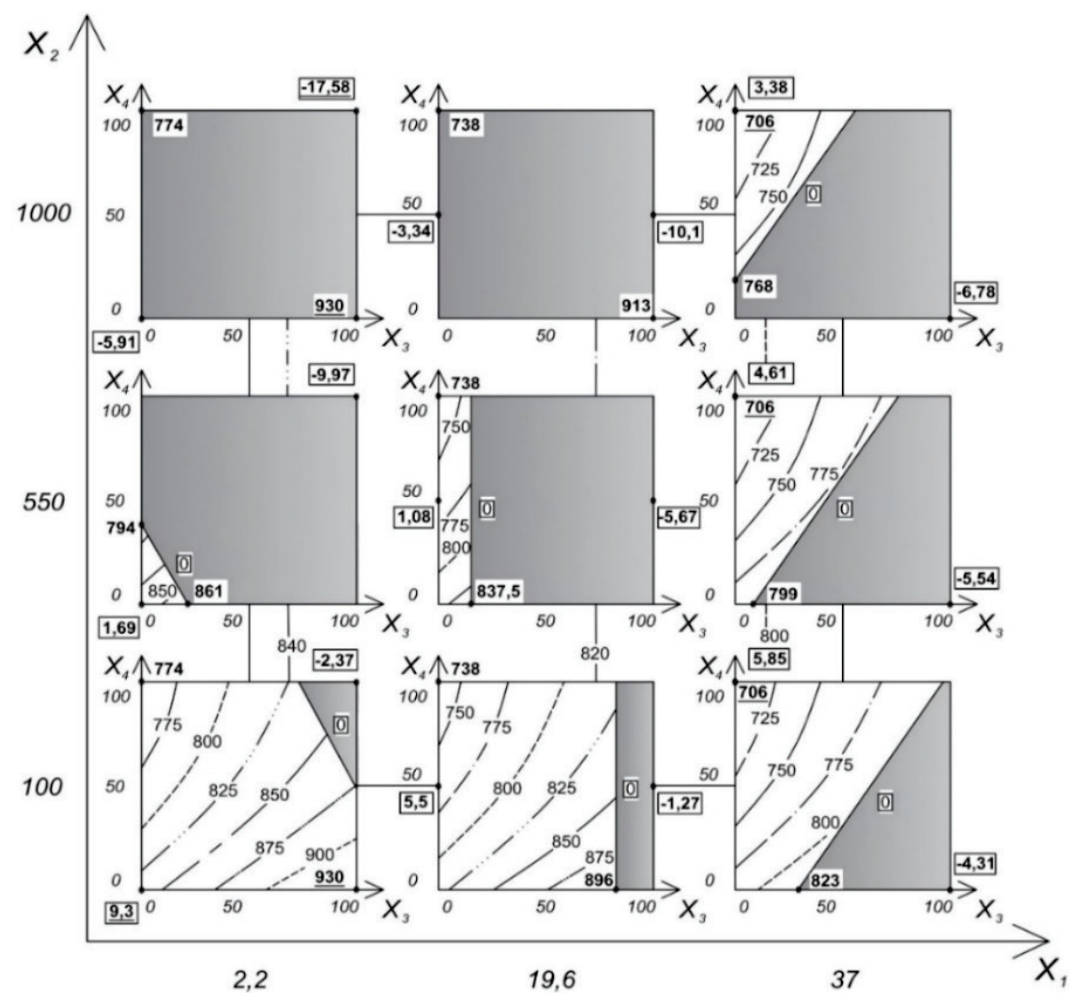

Figure 11 Optimization of cost of conveyor section installation, $Y_{6}(\mathrm{UAN} / \mathrm{m})$ influenced by membership of resources used $\left(X_{3}, \%\right)$ and industriality of applied solutions $\left(X_{4}, \%\right)$ at various strategic solutions of the enterprise management and under limitation of $Y_{1} \geq 0 \%$

\section{RATIONALIZATION OF MANAGERIAL DECISIONS OF GRAIN STORAGES CONSTRUCTION AND RECONSTRUCTION}

Multidimensional structure, presented in Fig. 4, allows to group projects executed by the organization, depending on their scale $\left(X_{1}\right)$ and territorial diversity $\left(X_{2}\right)$. This makes it possible to analyze organizational and technological interrelationships between similar projects. In the framework of individual projects, different organizational and technological solutions are possible $\left(X_{3}, X_{4}\right)$. The model shows that there is a connection between the structure of the construction enterprise (DCC) and the management of the construction enterprise (MCE), as well as between the structure (WBS) and the management methods (MCP) of individual projects.

Let us consider examples of companies that have chosen as a development four combinations of strategic organizational and technological decisions:

1. Focusing on objects of a large scale and labor intension, which are located at a considerable distance from each other: MCE $\supset\left\{X_{1} \rightarrow 37\right.$ thousand hours; $X_{2} \rightarrow 1000$ $\mathrm{km}\}$.

2. Focusing on small objects located within a limited area: $\mathrm{MCE} \supset\left\{X_{1} \rightarrow 2.2\right.$ thousand hours; $\left.X_{2} \rightarrow 100 \mathrm{~km}\right\}$.

3. Focusing on large and small objects in the ratio of direct costs $75 \%$ to $25 \%$ : MCE $\supset 0,75\left\{X_{1} \rightarrow 37\right.$ thousand hours.; $\left.X_{2} \rightarrow 1000 \mathrm{~km}\right\} \cup 0,25\left\{X_{1} \rightarrow 2.2\right.$ thousand hours; $\left.X_{2} \rightarrow 1000 \mathrm{~km}\right\}$.
4. Focusing on large and small objects in the ratio of direct costs $25 \%$ to $75 \%$ : MCE $\supset 0,75\left\{X_{1} \rightarrow 2.2\right.$ thousand hours; $\left.X_{2} \rightarrow 1000 \mathrm{~km}\right\} \cup 0,25\left\{X_{1} \rightarrow 37\right.$ thousand hours; $\left.X_{2} \rightarrow 1000 \mathrm{~km}\right\}$.

In the case of intermediate combinations, the proposed solutions require appropriate adaptation.

For combinations 1, 3, 4, there was selected the biggest value of the factor "average relocation distance" $\left(X_{2}\right)$ as it is the most likely to perform work on various distance in case of an objects totality.

Character of the interactions for each of the strategic combination of organizational and technological solutions contains in Tab. 5. Tab. 6 describes features of the management of enterprises, which construct dispersed different scale buildings, depending on their orientation on own $\left(X_{3} \rightarrow 0 \%\right)$ or contracted $\left(X_{3} \rightarrow 100 \%\right)$ resources, high $\left(X_{4} \rightarrow 100 \%\right)$ or low $\left(X_{4} \rightarrow 0 \%\right)$ degree of industrialization of used technological solutions.

The enterprise prepares so that project managers can be recruited from among the existing managers (heads of departments and heads of construction sites) in case of change the organizational and technological conditions, bring them in from outside as needed. In case of unfavorable changes in the organizational and technical conditions, project managers are transferred to the post of heads of departments or construction sites, or their number is reduced.

Analysis of Tab. 5 showed that the main priority for the optimization of the grain storages construction enterprise are: organization of the relevant management system, in-line long-term work performance and optimal scheme of supply. 
Table 5 Management interactions between the elements of the enterprise operating activity, which construct grain storages

\begin{tabular}{|c|c|c|c|c|c|}
\hline \multirow{2}{*}{ 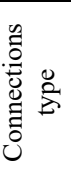 } & \multirow{2}{*}{ 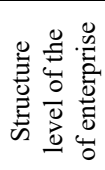 } & \multicolumn{4}{|c|}{ Combinations of strategic organizational and technological solutions } \\
\hline & & 1 & 2 & 3 & 4 \\
\hline 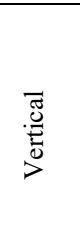 & $\frac{\frac{n}{0}}{\stackrel{0}{0}}$ & $\begin{array}{l}\text { Senior management has control } \\
\text { of project managers and makes } \\
\text { strategic decisions. The main } \\
\text { center of org. tech. solutions - } \\
\text { project management office. }\end{array}$ & $\begin{array}{l}\text { Senior management is } \\
\text { involved in the management } \\
\text { of all projects and executes } \\
\text { them according to the } \\
\text { department division of } \\
\text { responsibilities. }\end{array}$ & $\begin{array}{l}\text { Senior management has control } \\
\text { of project managers and makes } \\
\text { strategic decisions. One or more } \\
\text { of project managers and their } \\
\text { teams manage a portfolio of small } \\
\text { projects. }\end{array}$ & $\begin{array}{l}\text { Senior management is involved in } \\
\text { the management of all projects } \\
\text { and executes them according to } \\
\text { the department division of } \\
\text { responsibilities. Heads of } \\
\text { departments are appointed } \\
\text { responsible for major projects. }\end{array}$ \\
\hline \multirow{4}{*}{ 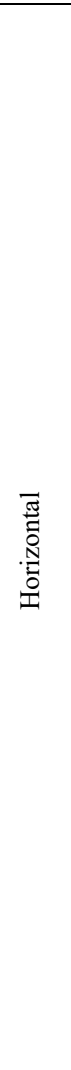 } & 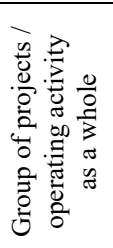 & $\begin{array}{l}\text { The management team is formed } \\
\text { for each project. The team } \\
\text { performs all the functions of } \\
\text { engineering, economic and } \\
\text { material supplies for the project. }\end{array}$ & $\begin{array}{l}\text { Management of all projects is } \\
\text { carried out by departments } \\
\text { that perform each of its } \\
\text { production function. }\end{array}$ & $\begin{array}{l}\text { Management of portfolio of small } \\
\text { projects (multi-project) is } \\
\text { assigned to the separate team. } \\
\text { Management of large projects is } \\
\text { performed according to } \\
\text { combination } 1 .\end{array}$ & $\begin{array}{l}\text { The workers within the functional } \\
\text { departments of the organization } \\
\text { are assigned for a large project. } \\
\text { The rest of the staff is involved in } \\
\text { the projects' management } \\
\text { according to combination } 2 \text {. }\end{array}$ \\
\hline & $\begin{array}{l}\frac{n}{0} \\
\frac{0}{2} \\
\vdots \\
\vdots\end{array}$ & $\begin{array}{l}\text { Participation / non-participation } \\
\text { in the project and its linkage with } \\
\text { other projects of the organization } \\
\text { is measured by the presence of a } \\
\text { sufficient number of project } \\
\text { management personnel. With a } \\
\text { lack of resources, they are } \\
\text { involved from outside. }\end{array}$ & $\begin{array}{l}\text { Participation / non- } \\
\text { participation in the project } \\
\text { and its linkage with other } \\
\text { projects of the organization is } \\
\text { measured by the presence of } \\
\text { labor and / or equipment. } \\
\text { Management personnel can } \\
\text { be engaged from outside. }\end{array}$ & $\begin{array}{l}\text { The decision on participation / } \\
\text { non-participation in the project is } \\
\text { carried out according to } \\
\text { combination } 1 . \text { Multi-project in } \\
\text { this case is treated as a separate } \\
\text { project. }\end{array}$ & $\begin{array}{l}\text { The decision on participation / } \\
\text { non-participation in the project is } \\
\text { carried out according to } \\
\text { combination } 2 \text {. }\end{array}$ \\
\hline & 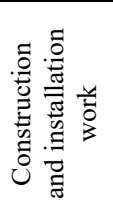 & $\begin{array}{l}\text { It is vital to organize rationally } \\
\text { planned engineering workflows } \\
\text { within individual projects with } \\
\text { their subsequent linkage between } \\
\text { projects. }\end{array}$ & $\begin{array}{l}\text { Work is intensified, and } \\
\text { slowed down according to } \\
\text { the workspace at other sites, } \\
\text { in order to develop the } \\
\text { company overall continuity } \\
\text { of the process flow. }\end{array}$ & $\begin{array}{l}\text { The portfolio of small projects } \\
\text { considered as a multi-project with } \\
\text { appropriate org. tech. linking } \\
\text { work within it. Active flows link } \\
\text { large projects and multi-project. }\end{array}$ & $\begin{array}{l}\text { Repeats approach for } \\
\text { combination 2. Major project } \\
\text { receives priority in the overall } \\
\text { enterprise for organizational and } \\
\text { technological linking of works. }\end{array}$ \\
\hline & 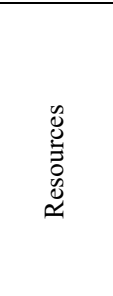 & $\begin{array}{l}\text { Resources for projects are } \\
\text { provided by the project } \\
\text { management team. Sharing } \\
\text { resources between projects } \\
\text { impossible or severely restricted. } \\
\text { Sharing human resources and } \\
\text { technology available only at the } \\
\text { end of their work on the } \\
\text { technological flow. }\end{array}$ & $\begin{array}{l}\text { Projects are centrally } \\
\text { provided with resources by } \\
\text { the department of logistics. } \\
\text { Intensive sharing of } \\
\text { resources between projects is } \\
\text { encouraged. Necessary for } \\
\text { specialized work human } \\
\text { resources and equipment are } \\
\text { transported. }\end{array}$ & $\begin{array}{l}\text { Supply of resources is performed } \\
\text { in two ways: individually for each } \\
\text { major project and centrally for } \\
\text { small projects portfolio. } \\
\text { Approaches are combined } \\
\text { according to combinations } 1 \text { and } \\
2 \text {. }\end{array}$ & $\begin{array}{l}\text { Supply of resources is centralized } \\
\text { with the priority of major } \\
\text { projects. }\end{array}$ \\
\hline
\end{tabular}

Table 6 Peculiarities of operating businesses in grain storages construction in the orientation on the different ownership of resources used and industrialization of solutions used

\begin{tabular}{|l|l|l|l|}
\hline \multicolumn{1}{|c|}{$\left(X_{3} \rightarrow 0 \%\right)$} & \multicolumn{1}{|c|}{ Attribution of resources $\left(X_{3}\right)$} \\
\cline { 2 - 4 } & & \multicolumn{1}{|c|}{$\left(X_{3} \rightarrow 100 \%\right)$} \\
\hline
\end{tabular}


The algorithm for calculating the income of grain storages construction and reconstruction enterprises is shown in Fig. 12. According to this figure, the general production cost should be calculated in detail, since the cost of these items is different for each individual project. In addition, enterprises shall determine the amount of monthly administrative costs and desired profit level, based on the timing and composition of already implemented construction projects. As a general rule, the longer the lifetime of the project is and the smaller implemented projects are, the greater the level of administrative costs is put in bids on the project. The amount of profit is determined from the same parameters.

1) Analysis of project documentation, calculation of physical volumes of construction and installation works. Calculation of direct costs.

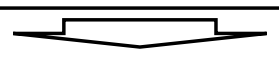

2) Analysis of organizational and technological solutions that can be used. Analysis of the resource provision of work

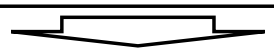

3) Calendar-resource modeling of the construction project.

4) Calculation of general production costs based on the relocation of the necessary resources, engineering and technical support of the construction site.

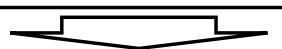

5) Calculation of administrative costs and the desired level of profit based on the timing of the project and contractor's projects that are already being implemented. Determining the final bid price.

Figure 12 The algorithm for income calculating of grain storages construction and reconstruction enterprises

\section{CONCLUSIONS}

- Analysis of information sources on the study allowed confirming the high relevance of the present study and justifying the a priori positions.

- The developed method of experimental statistical simulation allowed numerical optimizing of the operating activity of grain storages construction and reconstruction enterprise.

- The proposed model of the operating activity of the grain storages construction and reconstruction enterprise made it possible to theoretically substantiate the link between organizational and technological decisions for the management of individual construction projects and operating activity of the enterprise as a whole.

- The minimum cost of construction products was observed at: $X_{1}=37$ thous. hours. ("average labor input of the projects totality"); $X_{2}=100 \mathrm{~km}$ ("average relocation distance"); $X_{3}=0 \% \quad$ ("membership of resources used"); $X_{4}=100 \%$ ("industriality of applied solutions"). It is as follows:

- for reinforced concrete structures unit $\left(Y_{2}\right)-3.14$ thous. $\mathrm{UAN} / \mathrm{m}^{3}$;
- for load-bearing metal structures unit $\left(Y_{3}\right)-4.16$ thous. $\mathrm{UAN} /$ ton;

- for grain silo storage installation $\left(Y_{4}\right)-34.88 \mathrm{UAN} / \mathrm{m}^{3}$ storage;

- for noria section installation $\left(Y_{5}\right)-1.08$ thous. UAN $/ \mathrm{m}$.;

- for conveyor section installation $\left(Y_{6}\right)-706 \mathrm{UAN} / \mathrm{m}$.

- Designed recommendations are ready for use in order to rationalize the management of companies under consideration.

- The developed method allowed justification of raising of the standard level of income of companies which construct grain storages. The estimated amount of income should be separately justified and fixed in the contract on the basis of the principles of the project management approach.

\section{REFERENCES}

[1] Informational portal "Proagro". (2019). Retrieved from http://www.proagro.com.ua

[2] Koval'chuk, I. (2019). Elevator - as an object of evaluation. Retrieved from http://vital-profi.com.ua/publications/elevatorkak-obekt-ocenki/

[3] Mogalea, D. G., Kumara, S. K., Márquezb, F. P. G., \& Tiwaria, M. K. (2017). Bulk wheat transportation and storage problem of public distribution system. Computers \& Industrial Engineering, 104. 80-97. https://doi.org/10.1016/j.cie.2016.12.027

[4] Cabrera, J. (2017). Main trends in the grain storage industry. Retrieved from http://siloscordoba.com/2013/03/21/maintrends-in-the-grain-storage-industry-silos-of-biggercapacities/

[5] Gel'fand, R. (2017). Elevator industry has great potential for development in Ukraine. Retrieved from $\mathrm{http}: / /$ agrobuilding.com/interview/elevatornayapromyshlennost-ukrainy-imeet-ogromnyj-potentsial-dlyarazvitiya

[6] Bucklin, R. \& Thompson, S., Abdel-Hadi, A., \& Montross, M. (2007). Handbook of Farm, Dairy, and Food Machinery. Chapter 7 - Grain Storage Systems Design, 123-175. https://doi.org/10.1016/B978-0-12-385881-8.00007-0

[7] Tipovye organizacionnye struktury predprijatij [Typical organizational structures of enterprises]. (2016). Retrieved from http://www.cfin.ru/management/iso9000/iso900_ orgchart.shtml

[8] Kalinina, N. (2006). Enterprise modeling in the system of integrated controlling [Modelirovanie dejatel'nosti predprijatija $\mathrm{v}$ sisteme integrirovannogo kontrollinga]. Innovations [Innovacii], 7, 113-116.

[9] Fedoseev, V., Garmash, A., \& Dajitbegov, D. (1999). Economic and mathematical methods and applied models [Jekonomiko-matematicheskie metody i prikladnye modeli] (1st ed.). Moskva: JuNITI Publ.

[10] Donenko, V. (2011). Theoretical and methodological set of adaptive provision of building organizations development. Author's abstract. [Teoretiko-metodologichnij kompleks zabezpechennja adaptivnogo rozvitku budivel'nih organizacij. Avtoreferat Diss.]. Kiev

[11] Mlodec'kij, V. (2005). Organizational, technological and managerial reliability of construction enterprise functional system. Author's abstract. [Organizacijno-tehnologichna ta upravlins'ka nadijnist' funkcional'noï sistemi budivel'noï organizaciï. Avtoreferat Diss.]. Odessa. 
[12] Mjakishev, S. (2016). Multidimensional management structure of construction organization [Mnogomernaja struktura upravlenija stroitel'noj organizaciej]. Proc. of the VIII Int. Scientific and Practical Conf. [Tezisy VIII Mezhdunar. nauch.prakt. konf.]. Cheboksary. pp. 201-205.

[13] Lobakova, L. (2016). Organizational modeling of buildings reconstruction while their redevelopment. Author's abstract. [Organizacijne modeljuvannja rekonstrukciï budivel' pri ïh pereprofiljuvanni. Avtoreferat Diss.]. Odessa.

[14] Menejljuk, A., Ershov, M., Nikiforov, A., \& Menejljuk, I. (2016). Optimization of organizational and technological solutions of reconstruction of high-rise engineering structures [Optimizacija organizacionno-tehnologicheskih reshenij rekonstrukcii vysotnyh inzhenernyh sooruzhenij] (1st ed.). Odessa: Interservis Publ.

[15] Zadgenidze, I. (1976). Planning an experiment for the study of multicomponent systems [Planirovanie jeksperimenta dlja issledovanija mnogokomponentnyh system]. Moscow: Nauka.

[16] Nalimov, V., \& Golikov, T. (1980). Logical bases of experiment planning [Logicheskie osnovanija planirovanija jeksperimenta]. Moscow: Metallurgy [Metallurgija].

[17] Finny, D. (1970). Introduction to the theory of experiment planning [Vvedenie $\mathrm{v}$ teoriju planirovanija jeksperimentov]. Moscow: Nauka.

[18] Brodsky, V., Brodsky, L., \& Golikova, T. (1982). Tables of experiment plans for factor and polynomial models [Tablicy planov jeksperimenta dlja faktornyh i polinomial'nyh modelej]. Moscow: Metallurgy [Metallurgija].

[19] Cox, D. R. (1958). Planning of Experiments. New York: John Wiley

[20] Kempthorne, O. (1952). The Design and Analysis of Experiments. New York: John Wiley, https://doi.org/10.1097/00010694-195205000-00012

[21] Bose, R. C. \& Connor, W. S. (1960). Analysis of fractionally replicated 2"'-3" designs. Bull. de l'Inst. Intern. de Stat, 37(3), 141-160.

[22] Appelbaum, D., Kogan, A., Vasarhelyi, M., \& Yan, Z. (2017). Impact of business analytics and enterprise systems on managerial accounting. International Journal of Accounting Information Systems, 25, 29-44. https://doi.org/10.1016/j.accinf.2017.03.003

[23] Sikorová, E., Meixnerová, L., Menšík, M., \& Pászto, V. (2015). Descriptive Analysis and Spatial Projection of Performance among the Small and Middle Enterprises in the Olomouc Region in the Czech Republic in the Context of Accounting and Tax Legislation. Procedia Economics and Finance, 34, 528534. https://doi.org/10.1016/S2212-5671(15)01664-0

[24] Kumar, R. \& Vrat, P. (1989). Using computer models in corporate planning. Long Range Planning, 22(2), 114-120. https://doi.org/10.1016/0024-6301(89)90130-1

[25] Ministry of Regional Development, Utilities and Construction of Ukraine. (2013). Guidelines for the definition of general production, administrative costs and profits in construction costs: DSTU-N B D.1.1-3: 2013 [Rukovodstvo po opredeleniju obshheproizvodstvennyh i administrativnyh rashodov i pribyli v stoimosti stroitel'stva]. Kiyv.

[26] Ministry of Regional Development, Utilities and Construction of Ukraine. (2013). Rules for determining the cost of construction DSTU B D.1.1-1: 2013 [Pravila opredelenija stoimosti stroitel'stva DSTU B D.1.1-1: 2013]. Kiyv.

[27] Letter of the Ministry of Regional Development, Utilities and Construction of Ukraine "Recommendations for the determination of administrative costs, estimated profits, the cost of design and survey work, and examination of project documentation [Pis'mo Ministerstva regional'nogo razvitija, stroitel'stva i zhilishhno-kommunal'nogo hozjajstva Ukrainy "Rekomendacii po opredeleniju administrativnyh rashodov, smetnoj pribyli, stoimosti proektno-izyskatel'skih rabot, i jekspertizy proektnoj dokumentacii"]. (2017). Retrieved from http://www.minregion.gov.ua/wp-

content/uploads/2017/06/list-Minregionu-vid-09.06.2017----7-15-6135.pdf

[28] Calculation of general production costs at the stage of the contract price and during the settlement [Raschet obshheproizvodstvennyh rashodov na stadii dogovornoj ceny $\mathrm{i}$ pri provedenii vzaimoraschetov]. (2014). Collection Of Pricing In Construction From Msmeta, 6. Retrieved from https://msmeta.com.ua/view_vidpovidzapitannja_k.php?id=27

[29] Project Management Institute, Inc. (2017). A guide to the project management body of knowledge (PMBOK guide). Pennsylvania.

\section{Authors' contacts:}

Aleksandr Meneylyuk, Doctor in technical sciences, Full professor, Head of Department of Technology of building industry, Odesa State Academy of Civil Engineering and Architecture, ORCID ID: 0000-0002-1007-309X, e-mail: pr.mai@mail.ru

Aleksey Nikiforov, Assistant of Department of Technology of building
industry (Corresponding author)
ORCID ID: 0000-0001-7002-7055
Odesa State Academy of Civil Engineering and Architecture
2 (ap 1.), Kartamyshevsky Ln, Odessa, Ukraine, 65091
tel. (Fax) +38 (066) 3309054
e-mail: aleksey-nikiforov@mail.ua
e-mail: nikiforov.aleksey@yahoo.com

